\title{
Risk Management Analysis on Bancassurance Model in Bank of Communications Changchun Branch
}

\author{
Yunlei Huo ${ }^{1, \text { a }}$ \\ ${ }^{1}$ Jilin Business and Technology College, Changchun, Jinlin, China, 130507 \\ ${ }^{a}$ email
}

Keywords: Bancassurance, Bank of Communications Changchun Branch

\begin{abstract}
By studying the situation at Bank of communications Changchun Branch Bancassurance model in recent years, this paper introduce the risk of data income Bancassurance mode after the bank provided to the Bank of Communications Changchun Branch Bancassurance this model exists and the future will face risks, after the analysis of the risk in Bank of Communications Changchun Branch bancassurance model, this paper presented the Bank of Communications Changchun Branch bancassurance model development proposals to achieve the fundamental purpose of profit, to promote the Bank of Communications other bancassurance model with common development, so that the Bank of Communications Changchun Branch continue to advance in the tide of development.
\end{abstract}

\section{Introduction}

Through several Changchun Branch of Bank of Communications to conduct business in Changchun Branch of Bank of Communications found that sales of bank and insurance products, there are many loopholes in place, and these vulnerabilities are triggered vicious competition Changchun Branch of Bank of Communications, which also can be said It is very different from cooperation and management of Changchun branch to work with insurance companies. We can not produce this problem due to one body, but two-party or multi-party needs to share the burden. Because the insurance company's business development too immature market is not full, and too intense competition among banks which led to problems. Bank of Communications Changchun Branch over control of the network, but also a mature performance, this immaturity led to the insurance company can not own in Bank of Communications Changchun Branch of insurance products and conduct surveys to grasp, and, of Changchun Branch control over banking and insurance products also make insurance companies can not make the pricing of their products, because the insurance company's insurance products are to be used by sales agents Changchun branch, so the price from Changchun branch to set up, more or less. This has led to most of the bancassurance model contract with the insurance company Changchun Branch signed are short term, not exceeding one year. This Changchun Branch of Bank of Communications Bancassurance model of development is extremely unfavorable. Because Changchun Branch control over their own outlets, insurance companies also began in this unfavorable situation for themselves in order to survive. So it caused the competition commission, the insurance companies to raise fees, thereby curbing Changchun Branch control of its network, which is called competition commission, this commission not only do no good, but to make the operating costs of their mutual It has been increased to some extent, but also due to increased fees, product replacement rate of decline in bank and insurance products to customers prohibitive, resulting in a large loss of customers.

At present, the development of Changchun branch bank and insurance business was shifted to deformity of the situation, mainly in the following points:

First, fees vicious competition. As we said earlier, the insurance company in order to snatch the Bank of Communications Changchun Branch controlled by the network, and to improve the handling of its insurance products, and Changchun branch network in order to firmly in their own hands, nor to the implementation of some of the play a regulatory effect of their own rules and regulations, which led to both sides because of the sales outlets engaged in ongoing game, both 
sides intensified competition fee.

Here, the excessive competition is excessive price competition, since it already had a competitive fee, then the price competition of course will also derived, which indicates whether the insurance company or the person who Changchun Branch, in the prices are not a good, comprehensive understanding, only the pursuit of immediate interest is the root cause of a little Changchun branch bancassurance model of development for a long time could not be better. To develop long-term good of the Bancassurance model, plainly, is to rely on the two sides more professional, meticulous and thoughtful to speak.

Now more important point is worthy of our attention. Whether Changchun branch or insurance company, you want to get profit by what is, must rely on the customer, the customer is the only God, no customer revenue comes from. She says, but now the practice of Changchun Branch something wrong. Changchun branch of his bank and insurance products brought their own business to jointly promote its original, it is easy to give the masses the illusion that this is not a business of insurance is owned by your bank, addition is the use of original accumulation customer confidence to allow customers to buy the bank and insurance products, doing so can easily lead to the loss of customers, because when customers no longer trust banks, the banks can not even sell their own products, when talk about bancassurance.

What is the most important point to attract customers and is the product replacement rate. Now Bank of Communications Changchun Branch of banking and insurance products there is a very big drawbacks, banking and insurance products is too dull, and customers for months to come is that banking and insurance products, or several months after this banking and insurance products even after a year, or same type of banking and insurance products, so that customers will choose other stores the new bank and insurance products, which again resulted in loss of customers. Of course, the reason is not just the cause of Changchun Branch alone, where there are reasons for cooperation, including insurance companies. Bancassurance as a model of both "sideline", by the degree of attention we imagined so high, it was a result of a single bank and insurance products. This is the Bank of Communications Changchun Branch banking and insurance products to attract customers to the lack of reason, which also indirectly led Changchun Branch Changchun also among the country's banks, or lack of competitive reasons.

\section{Development Proposals of Bancassurance Model in Bank of Communications Changchun Branch}

Insurance companies and the Bank of Communications Branch, Changchun should be more active to design Bancassurance products more suited Changchun Branch sales promotion, it should be from the product is suitable for development, whether the product is suitable for sales, product explanation if more convenient, the product is easier the bank accepted by the customer and other aspects to consider, so the enthusiasm of Changchun branch fully mobilized. Moreover, not turning a blind eye Changchun Branch, Changchun Branch is the first line of selling banking and insurance products, the burden even heavier, he has to add taking into account the common interests of its clients, including the three, coordinate the relationship between the three, is to make Bank of Communications Changchun Branch foundation better development.

Currently, Bank Bancassurance model Changchun Branch or domestic Or Bancassurance model for other large banks in the world has not a small gap, which with slow economic development in Changchun also has some reasons, largely influenced Changchun branch bancassurance development cooperation model. So we have to only select the above fuss marketing mix, how to make a reasonable combination of new product development, promotion, sales, aftermarket, is the primary problem.

Now, the market is flooded with a myriad of insurance and banking and insurance products, in order to stand out from where to obtain the favor of the customer base as well as trust, rely on new marketing mix. Now bancassurance cooperation between China's domestic banks marketing mix basic pattern not much different, which rely on foreign Changchun Branch actively marketing to learn new ideas, "its essence, to its dregs." In the new marketing mix is to attract customers' 
attention.

Changchun Branch now with the insurance company can bancassurance model through cooperation model, but because of our system, banks and insurance companies to merge or not. However, some banks and insurance companies another way, through the bancassurance model is banks and insurance companies formed a mutually supportive situation. This situation undoubtedly long-term cooperation of banks and insurance companies play an important role for the benefit of banks and insurance companies share has laid a solid foundation. This is undoubtedly exciting, but happy at the same time, we must always pay attention to changes in the law on our bancassurance model, because in perfect Bancassurance legal environment this premise, banking and insurance companies develop such a win-win mode will advance towards a healthy condition.

Improve the legal environment bancassurance model, even if the competition alleviates Changchun Branch of Bank of Communications and cooperation among insurers. Let us imagine, if the policy Bancassurance model to get national attention, the holders of these "tickets" by the insurance company will continue to improve their product development, product competitiveness and efforts; bank employees will customer service and greater efforts in general is constantly improving itself, and no time to continue immature outlets, fee competition. This being insured us is undoubtedly a very good news, let's think about ourselves, when cooperative banks and insurance companies in the true sense of whether our banks or insurance companies will continue to reliability rise, increased our demand for the purchase of new bancassurance products. So that we can be more assured that the choice is more suitable for us, we are more in line with their own conditions of banking and insurance products.

\section{References}

[1] Huang Hanxin. SWOT analysis and strategic bancassurance cooperation [J]. Hainan Finance, 2013

[2] Zheng Rongnian. Banks and insurance companies to choose background Mixed Mode [J]. Insurance Research, 2014, (3)

[3] Zhao Hui. Bancassurance cooperation model study [D]. Harbin Engineering University, 2014, 10, 15 (010)

[4] $\mathrm{Hu}$ Ranhua. The insurance cooperative mode of Chinese banking on the background of the financial crisis [J]. Financial and economic, 2013

[5] Manoj Kumar. Bancassurance: A SWOT Analysis (wish special reference to Indian Market) [J]. IRDA. 2004(03):32-37

[6] Corinne Legrand. New trends in world bancassurance[J]. Milliman Globalfirm. 2004 (07): 28-32. 